\title{
"Tristeza não tem fim, felicidade sim" (?): dramas humanos presentes em Orfeu da Conceição em diálogo com a Escatologia Cristã
}

\author{
Orientador: Cesar Augusto Kuzma
}

Doutorando: Cleber Diniz Torres

Área de Concentração: Teologia Sistemático-Pastoral

Linha de Pesquisa: Fé e Cultura

Projeto de Pesquisa: A esperança cristã e as questões atuais de Escatologia

O presente trabalho procura desenvolver mais um diálogo entre teologia e literatura. Tomando como referenciais a escatologia cristã e Orfeu da Conceição de Vinícius de Moraes, a pesquisa discorrerá sobre temas como sofrimento, morte e luto, correspondentes entre si nestas suas fontes principais, visando encontrar contribuições para uma teologia mais relevante e acessível. Num primeiro momento, serão levantadas as informações a respeito do poeta e sua obra especificando informações relativas à peça teatral com vistas a demonstrar como nela é expresso, da parte do poeta, opiniões sobre os temas do sofrimento, da morte e do luto. Para isso serão examinadas: as questões relativas à violência presente nas brigas descritas pelo poeta; as duas mortes ocorridas na narrativa; e, os lutos vividos pelas personagens da peça. Num segundo momento, serão apresentados pareceres teóricos da teologia relativos aos temas do sofrimento, em suas causas e em sua presença incontestável na realidade humana; da morte, entendida como parte constitutiva da vida e como expressão limite da existência; e do luto, enquanto expressão de amor do enlutado por aqueles que se foram. Essas proposições têm por objetivo acrescer à pesquisa a chave de leitura da peça teatral, a fim de desenvolver sustentação teológica para o diálogo pretendido. Num terceiro momento, a pesquisa realizará a síntese entre os dos campos do saber, a literatura e a teologia, demonstrando suas correspondências entre os temas do sofrimento, da morte e do luto em ambas e contribuições por elas oferecidas para o campo teológico.

Palavras-chave: Literatura. Escatologia. Vinícius de Moraes. 